its flora. The "Flora of Tropical Africa" was begun by $\mathrm{D}$. Oliver in 1868 , and has been carried on by many botanists, part of the last family, the Gramineæ, commenced by O. Stapf and now being continued by C. E. Hubbard, only remaining to complete the huge task. The work of editing this great undertaking has been earried out by successive directors of Kew, Sir William T. Thiselton-Dyer, Sir David Prain, and Sir Arthur W. Hill, and part of the Euphorbiaceæ was contributed by Sir David Prain.

The "Flora of West Tropical Africa" (1927-36), by J. Hutchinson and $J$. M. Dalziel, is the first regional illustrated flora of the tropical part of the Continent; its "Economic Appendix" by J. M. Dalziel provides full information on the uses of West African plants. Smaller areas are dealt with in the "Flora of Liberia" (1906), by O. Stapf (in Johnston, "Liberia") ; "Trees and Shrubs of Sierra Leone" (1916) by C. E. Lane Poole ; "Gold Coast Trees and Shrubs" (1913), T. F. Chipp ; "Nigerian Trees" (1925), H. V. Lely ; "Flora of the Sudan" (1929), A. F. Broun and R. E. Massey, and its companion volume of illustrations by G. M. Crowfoot (1929); "Trees of Kenya Colony" (1926), E. Battiscombe ; "East African Grasses" (1926-27), by C. E. Hubbard.

The islands of Mauritius and the Seychelles wero provided for in J. G. Baker's "Flora" (1877), and latterly the "Seychelles Flora" has been cnumerated by V. S. Summerhayes.

The immense task of describing the rich and varied flora of what is now the Union of South Africa, begun by Harvey and Sonder in 1859, the "Flora Capensis", was continued by the Kew staff and others and completed in 1935. As in the case of the "Flora of Tropical Africa", the editorship has been in the hands of successive directors of Kew, Sir David Prain and Sir Arthur Hill also contributing largely to the taxonomic work. The "Flora of the Transvaal" (parts 1 and 2, 1926-32), by J. Burtt Davy, is the first of the regional descrirtive floras of South Africa. The descriptions for Mrs. E. F. Vallentin's "Illustrations of the Flowering Plants and Ferns of the Falkland Islands" were provided by Mrs. E. M. Cotton.

A. H. R. Grisebach's "Flora of the British West Indian Islands" was written in association with
Kow ; and the "Flora of Trinidad" (1928- ), by Williams and Cheesman, is also being prepared in close collaboration with Kew.

Among the general works by individual Kew botanists are the "Synopsis Filicum" (1868), of W. J. Hooker and J. G. Baker; the "Fern Allies" (1887), by J. G. Baker; "British Fungi" (1906), G. Massee ; "Diseases of Cultivated Plants and Trees" (1910), G. Massee; and J. Hutchinson's new phylogenetic classification in his "Families of Flowering Plants" (1926; 1935). "Plant Life in the Balkan Peninsula", W. B. Turrill (1929), is an intensive study of a special area.

Researches in sixtecnth century botany are represented by the "Herbal of Otto Brunfels", by T. A. Sprague (1928), and the "Herbal of Leonhart Fuchs", by T. A. Sprague and E. Nelmes (1931).

Applied botany is the subject of J. Smith's "Dictionary of Economic Plants" (I882), and his "Domestic Botany" (1871); G. Watt's monumental work, "A Dictionary of the Economic Products of India" (1889-93(6)), and jts abridgment, "The Commercial Products of India" (1908); the "Economic Produets of the Malay Peninsula" (1935), I. H. Burkill ; "Useful Plants of Nigeria" (1908-22), by J. H. Holland ; "Tropical Agriculture" (1929), revised by J. H. Holland; "Sorghum" (1936), J. D. Snowden ; "Crop Plants of the British Empire" (1936), by H. C. Sampson.

Among the more important books on horticulture and forestry are the "Dictionary of Gardening" (1884-88), by G. Nicholson; "The Trees of Great Britain and Ireland", H. J. Elwes and A. Henry 1905-13); "Trees and Shrubs Hardy in the British Isles" (1921), by W. J. Bean; "Rhododendrons" (1930), by $J$. Hutchinson (Kew), A. Rehder and $H$. Tagg (published by the Rhododendron Society); "Coniferæ" (1923), by W. Dallimore and A. Bruce Jackson, and the periodical, the Orchid Review (1893- ), founded and edited for many years by the late R. A. Rolfe. 'The history of the Gardens is dealt with in "The Royal Botanic Gardens, Kew" (1908), by W. J. Bean.

This list does not include, of course, the numerous smaller papers in scientific journals to which the Kew staff has so largely contributed.

\title{
Calculating Machines in Scientific Computing
}

$S^{c}$ IENTIFIC computing has been materially aided of late years by the development of calculating machines, a development in which scientific workers themselves have had a say. We may instance the use of the modern Brunsviga, with its split register and automatic transfer features, in statistical calculations; the application by Dr. L. J. Comrie of the Brunsviga twin 13z to the Hartmann formula for the reduction of prismatic spectrograms; the use of the Burroughs machine, and later the National Cash Register machine, in the Nautical Almanac Office for finite differencing and integration; the demonstration recently given at Cambridge of the application of the Hollerith rolling-total tabulator for the same purpose, and for general statistical calculations; the machine invented by Mr. R. R. Mallock at Cambridge for solving simultaneous equations; and the Bush machine developed at the Massachusetts Institute of Technology for the numerical solution of differential equations, and since installed by Prof. D. R. Hartree at Manchester.

For some years, the Mathematical Tables Committee of the British Association has conceritrated on the production of new tables by means of sub. tabulation on its "National" machine, a process which has revolutionized the art of table-making; the incidental advantage of having clean type copy produced by the machine for the printer has largely eliminated copying and setting errors. Checking by means of mechanical differencing of tables is equally 
easy. With regard to the Hollerith, the spectacular production of a table of a polynomial function by feeding the machine with blank cards appealed to many at the Cambridge demonstration, while so far as capacity for work is concerned, it may be mentioned that in a recent agricultural statistical investigation, two Cambridge workers produced a million products in six weeks, that is, at the rate of one product a second.

Expensive machines are not readily available to the ordinary scientific worker, and this lends interest to the announcement that Dr. Comrie, formerly superintendent of H.M. Nautical Almanac Office, to whom much of the above mentioned development is due, has set up at 131 Maze Hill, Blackheath, London, S.E.3, a professional "Scientific Computing Service". Dr. Comrie offers his services for (1) scientific calculations generally, and particularly those where mochanical computation and mass production methods may be employed; (2) tablemaking ; (3) purchase and use of calculating machines and mathematical tables; (4) instruction in the art of mechanical computing; (5) press work; and (6) lectures on calculating machines or on computing. He has at his command a variety of machines, includ- ing a "National" and Hollerith equipment. As the former is expensive to buy and the latter to hire, here is a means whereby the scientific worker may get computation jobs done efficiently at reasonable rates.

An interesting announcement from Cambridge relates to the proposed establishment of a computing laboratory in the mathomatical faculty. The immediate intention is to acquire a Bush integrating machine and the Mallock equation solver, but other machines will be added from time to time, and a wide view is being taken of the service that can be rendered to Cambridge by the establishment of such a laboratory. Besides the applied mathematicians; we can envisage statisticians, economists, biologists, psychologists and others being eager to avail themselves of the specialized equipment that will no doubt be available in time, in order to supplement their existing computational resources. The capital cost of the proposed installation is of the order of $£ 10,000$, and it is anticipated that an annual charge of $£ 1,000$ per annum will fall to be met by the University, to include maintenance and replacement of machines, and salaries. The scheme has been approved, and the laboratory should be in existence by the opening of the academic year in 1938 .

\section{Hybrid Vigour in Plants}

$I^{N}$ CREASED vigour over either parent of the product of the cross between two inbred lines has been frequently reported in plant breeding and, through vegetative propagation, ciforts have been made, especially with trees, to make practical use of the phenomenon. It is usually explained, in Mendelian terminology, as the result of association of several genes for size which had been isolated in either parent, and subsequent loss of vigour in succeeding generations is attributed to segregation. There has been little analysis, however, of the factors contributing to the heterosis or hybrid vigour during the development of the hybrid, so that considerable interest is attached to a recent series of papers by Dr. Eric Ashby, which havo brought to light some most unexpected features of this process in specific cases.

In certain strains of maize ${ }^{1}$ and in two cases with tomato strains ${ }^{2}$ where the hybrid showed greater weight and dry weight, greater height, more leaves and larger leaf area than either parent, analysis of these differences showed no appreciable difference between hybrid and parent in relative rates of growth or of dry weight increase, of rates of production of leaves and new leaf area or of photosynthetic efficiency. Cell size in hybrid and parent also seemed approximately the same, but the embryo of the resting seed seemed larger in all cases.

The only possible conclusion from these results would seem to be that the organization of the growing shoot of the hybrid is upon a larger scale. Embryo and shoot apex form cells more rapidly, but this does not result in a quicker release of leaf primordia from the shoot apex because the whole plan of shoot organization, though still that characteristic of the species, is built upon a larger scale. More cells must accumulate at the apex before the new leaf primordium must separate. Naturally, therefore, when it arises, this primordium is planned on a larger scale from the outset, presumably its procambial and vascular strands are commensurately larger and it grows into a larger leaf, though individual cells, in their metabolic and photosynthetic efficiency, correspond with those of the parent forms.

Dr. Ashby speaks of larger primordia in the seed, but the term is usually applied to leaf primordia, and in the embryo of the tomato, apart from cotyledons, leaf primordia will scarcely be manifest yet. It would seem that the comparison is rather upon the scale of organization of the meristematic aggregate in the hybrid shoot; planned on a more generous scale, it yet maintains the rate of leaf development of the parent, so that its growth must mean a larger number of meristematic cells maintained in full activity at any moment, therefore more cell divisions and the growth organization of the species main. tained at its usual tempo but on a larger scale.

Dr. Ashby's studies are therefore full of significance in relation to the problem of shoot organization in the higher plant, as well as in connexion with the genetic explanation of hybrid vigour. Dr. Ashby points out that his results are not in accordance with the usual interpretation given to the linkage of genes in the $F_{1}$ generation, but there is as yet so little information as to the way in which the gene is geared into the machinery of development that it is early to say whether the conventional explanation in terms of genes can be applied to the machinery now revealed as operating in the development of the hybrid.

${ }^{1}$ Ann. Bot., 44 (1930) and 46 (1932).

${ }^{2}$ Ann. Bot., X.S., 1, 11-12 (1937). 